Citation: Fuentes-Luque, A. \& GonzálezIrizarry, P.L.. (2020). Understanding the Urgent Need for Subtitling for the Deaf and Hard of Hearing in the SpanishSpeaking Greater Antilles. Journal of Audiovisual Translation, 3(2), 286-309.

Editor(s): A. Matamala \& J. Pedersen

Received: February 1, 2020

Accepted: July 22, 2020

Published: December 21, 2020

Copyright: @2020 Fuentes-Luque \& González-Irizarry. This is an open access article distributed under the terms of the Creative Commons Attribution License. This allows for unrestricted use, distribution, and reproduction in any medium, provided the original author and source are credited.

\section{Understanding the Urgent Need for Subtitling for the Deaf and Hard of Hearing in the Spanish-Speaking Greater Antilles}

\author{
Adrián Fuentes-Luque ${ }^{\bowtie}$ \\ Universidad Pablo de Olavide \\ Pabsi Livmar González-Irizarry \\ Universidad Pablo de Olavide
}

\begin{abstract}
Even though audiovisual translation (AVT) is growing and flourishing throughout the world, it is practically unheard-of in the Caribbean, where accessibility faces an even bleaker existence. The circumstances of the deaf and hard of hearing (also referred to as D/deaf) are no less alarming: social barriers and exclusion are widespread. This paper emphasizes the need to make subtitles accessible in the Spanishspeaking Caribbean, specifically on the islands of Puerto Rico, Cuba, and the Dominican Republic, and underscores the challenges faced by the $D /$ deaf communities on each island. Our research focuses on issues like AVT laws and regulations, the habits of viewers of audiovisual (AV) products, and literacy and limitations on each island. This paper also examines the different types of $D /$ deaf audiovisual consumers in the Spanish-speaking Caribbean and the difficulties each community faces when accessing media and entertainment. Our research reveals the current state of AVT accessibility in this region and provides a foundation for influencing legislators to begin enforcing AVT regulations and drafting SDH guidelines.
\end{abstract}

Key words: audiovisual translation, subtitling for the D/deaf, viewing habits, AVT laws and regulations, accessibility, Caribbean, Spanish-speaking Greater Antilles.

afuentes@upo.es, http://orcid.org/0000-0001-9717-2519

pabsi.gonzalez@upr.edu, https://orcid.org/0000-0002-1802-2326 


\section{Introduction}

Latin America comprises a huge geographical area in which most countries have limited regulations concerning accessible audiovisual translation (AVT) and, so far, no guidelines for providing subtitles for the deaf and the hard of hearing (SDH). Translators who choose the path of this noble profession must begin pursuing this rewarding effort in their own backyards. Here is where accessibility, inclusion, and people with disabilities come into play. In accordance with general perceptions on the concept of "accessibility," which we will define in the next subsection, the deaf and hard of hearing, who will be referred to as "D/deaf" throughout this article, cannot and should not be considered an isolated group of people within the population of specific countries or societies. They should instead be regarded as people who experience life differently and who have communication systems that are different from those of the hearing population. Their experiences, rights, and opportunities should therefore be taken into consideration through initiatives, efforts, and actions that support their well-being and inclusion, such as providing films and videos with SDH. A close look at the statistics ${ }^{1}$ reveals that the world population is increasing by the day, and as a result, so is the number of $\mathrm{D} /$ deaf people. This should put all governments on alert. They should be continually drafting new and better plans to ensure equal rights and opportunities for their D/deaf communities. Deafness is, by all accounts, the sensory disability that most commonly leads to human isolation since it affects human development. Due to limitations in communication, early life experiences that contribute to personal development may not be adequate, and when they are indeed satisfactory, they are never comprehensive and complete (Ramos-Ramos, 2010, p. 93). D/deaf people have an urgent need for accessibility, not only from an architectonic perspective (to provide everyone with the capacity to access or inhabit a space regardless of their cognitive and physical capacities), but also in technological and audiovisual (AV) contexts, since there is a notable increase in the use and integration of video and technology in our daily lives.

\subsection{Accessibility of AV Products and the Importance of Accessible AVT}

AVT is a translation modality by which information is provided through the simultaneous combination of two different communication channels: vision and hearing. An AV product is therefore a type of text that must be seen and heard in order for the message to be received and understood. Some people with visual or hearing impairments are unable to receive information through these channels. Some others receive that information, yet it may not be complete or fully comprehensible. In order to ensure equal access to information, this content must be provided to them. The term "accessibility" plays a key role in guaranteeing people with visual or hearing impairments access to AV products. Alonso (2007) defines "accessibility" as the reduction of obstacles or barriers that restrict people with disabilities from efficiently assimilating into the population and attaining equal

\footnotetext{
${ }^{1}$ The U.S. and World Population Clock of the United States Census Bureau states that there are close to 7.8 billion people around the globe.
} 
rights with respect to quality of life and opportunities (p. 18). The concept of "universal accessibility" provides a framework for identifying the source of the barriers faced by individuals with disabilities, what can be done to prevent those barriers from resurfacing, and how to develop the measures, programs, and policies to ensure equality among all types of individuals within a population (Alonso, 2007, p. 18). Accessibility in AVT enhances experiences by implementing audio description (AD) for the blind and visually impaired, sign language interpreting (SLI), and subtitling for the deaf and the hard of hearing.

Audio description provides auditory information about the visual component of an AV product. Sign language interpreting occurs when a person performing language interpretation (from Spanish to Cuban, Dominican, or American Sign Language, for example) is shown on screen alongside the main speaker or placed in a square at either side of the bottom of the screen. Usually, the latter takes place in live scenarios like emergency broadcasts. Díaz-Cintas (2007) defines SDH as a type of written text "on the bottom of the screen" that aims to provide information about dialogue, intonation, sound effects, and other discursive elements on screen and/or in a foreign language, and other important aspects of the movie or AV product soundtrack, such as music and lyrics (p. 47). All AV products with SDH therefore comprise three elements: the oral discourse (dialogue and narration), the image, and the written discourse (subtitles). All SDH generally follow the same conventions as traditional subtitles (those without the written translation of sounds and voices overheard). As Díaz-Cintas (2007, p. 47) points out, they must consider the average reading speed of the target audience, be synchronized with the image, and include all elements of the original discourse necessary to convey the message.

It is of the utmost importance for the AV translation field not only to define film and video translation and subtitling norms, but also to create or adopt these norms based on the characteristics, social inclusion, and education level of the target audience. It must also ensure that translators use these norms as guidelines for decision-making that takes the time and space constraints that are inextricably linked to the subtitling process into consideration (Sokoli, 2005, p. 271). In this sense, AV translator training plays a crucial role in the development of media for all, and this training is just as important in the making of accessible films and videos as government support for accessibility and the enactment of laws that guarantee everyone the same rights. Neves (2008) indicates that AVT training within the educational system began in the late twentieth century, although specific emphasis on SDH became prominent in the early part of the twenty-first century. This training may include studies on the meaning of sound in films, the specifics of the working languages, basic notions of film composition, and the primary difference between SDH and traditional inter- or intra-linguistic subtitles. This is highly relevant since, as Neves (2008, pp. 171-172) puts it, the D/deaf "have limited or no access to sound and, in some cases, to the subtitles themselves due to low literacy skills." Studies into D/deaf literacy do not paint a uniform picture. Some D/deaf people read and write at the same level as their hearing peers, while others experience severe delay (Dammeyer \& Marschark, 2016, p. 394), hence why translators should consider the median literacy skills of the D/deaf in a specific society. D/deaf literacy is neither predicted based on the degree of hearing impairment nor 
the phonological skills (the ability to decode and process speech sounds). There are other factors to be considered: signed language and spoken language abilities, the school attended, degree of hearing loss, parental hearing loss, upbringing, etc. Literacy studies should be carried out in the Spanishspeaking Greater Antilles to have a clearer picture of the situation therein and later consider the median literacy skills of each $\mathrm{D} /$ deaf population to provide subtitles accordingly.

\subsection{A Brief Look at the International Context of AVT}

For their particular characteristic, silent films were equally accessible to both $D /$ deaf viewers and those with normal hearing ability, since they were based on the visual elements and sporadic intertitles ${ }^{2}$, which also were especially beneficial for the $D /$ deaf (if they could read, of course). This type of equal access to media has not been possible since the birth of sound films (Pereira-Rodríguez, 2005 , p. 163). However, more countries are adopting and adapting accessible AVT practices. In Europe, the BBC is the leading TV channel in the promotion of high-quality subtitling for the D/deaf (Pereira-Rodríguez, 2005 pp. 163, 166-167). Spain, on the other hand, is the guiding compass for stipulating SDH laws, regulations, and guidelines that aim to eliminate AV barriers for the D/deaf in the Spanish-speaking countries of Latin America. In Spain, the first SDH were screened by Televisió de Catalunya in 1990 followed by TVE (Televisión Española [Spanish public television]) two months later (Pereira-Rodríguez, 2005, p. 166). Even if the Spanish population prefers the dubbing of foreignlanguage films over subtitling, as is the case in many other countries, there is growing preference for subtitles for several reasons: Internet access at home, which includes access to online video streaming platforms such as Netflix, Hulu, and Amazon Prime; the ease with which captions can be turned on; the growth/proliferation of subtitled movies vs. dubbed movies due to financial constraints; $^{3}$ and the emergence of different video formats (DVD, Blu-ray, MP4, etc.) that enable users to choose between many screening options, such as dubbing, audio description, captions, interor intra-lingual subtitles, and SDH (Díaz-Navarro, 2016, p. 11). Pereira-Rodríguez argues that there is still a lot of room for improvement within the Spanish legal framework regulating media accessibility, and there is also an ever-growing interest in providing increased access to media to the $D /$ deaf and a strong desire to decrease or eliminate all communication barriers (2005, pp. 166-167).

\footnotetext{
${ }^{2}$ Intertitles or title cards were written, drawn, or printed text that was filmed and placed between movie scenes to provide the context, setting, important dialogue, or narration. The first known film with intertitles is Edwin S. Porker's Uncle Tom's Cabin (1903). J. Stuart Blackton, caricaturist and filmmaker, is recognized as the inventor of intertitles. The first ceremony of the Academy Awards included an Oscar for "Best Title Writing" which was awarded to Joseph W. Farnham for his intertitles in The Red Mill (1927).

${ }^{3}$ Since the dubbing process is more complex than subtitling and requires more labour in order to deliver the full translation, dubbing is costlier to filmmakers and producers when compared to subtitling.
} 


\subsection{Subtitling for the $D /$ deaf in the Americas}

AVT is practically unknown in the Caribbean: Almost no one speaks of it (Fuentes-Luque \& GonzálezIrizarry, 2019). The concept of accessibility is beginning to have a stronger voice among policymakers and academics; however, the practice of accessible translation is almost non-existent in the region. This, of course, constitutes a significant barrier to the $D /$ deaf accessing entertainment and $A V$ content in the way hearing individuals can. The general situation of the D/deaf in the Caribbean is alarming: social barriers and exclusion are common. Therefore, this article focuses on the urgent need for SDH in the Spanish-speaking Greater Antilles. The island countries of Cuba, the Dominican Republic, and Puerto Rico are located in the heart of the Antilles archipelago, a group of scattered islands in the Caribbean Sea where a mosaic of traditions and geographical, historical, and political backgrounds converge (Cruz, Guilbe, \& López, 2002, p. 37). The fact that most countries in Latin America share a similar history, culture, and language and that one of these three Greater Antilles islands is a territory of the United States calls for a brief survey of the accessibility and inclusion efforts in these geographical contexts.

In the United States, as a result of international AV product marketing and the arrival of Spanishspeaking immigrants from Latin America, private AVT providers have translated SDH manuals from English into Spanish in order to establish some sort of standardization in the subtitling industry. The best example of this is the Manual de Closed Caption [Closed Caption Manual] published in 2011 by the Described and Captioned Media Program (DCMP), a fundamental reference when producing SDH for the United States. It was translated by Dicapta, a company mostly dedicated to subtitling educational videos for the $\mathrm{D} /$ deaf. This digital booklet of guidelines is a true and correct translation of the original. In other words, it adheres to the requirements and format for closed captions in the United States, a primarily anglophone geographical context. The first English version of the Manual de Closed Caption was written in the 1950s and is still endorsed by the Department of Education of the United States.

In Latin America, Argentina was the first country to implement technological resources for subtitling (Instituto Nacional para Sordos - INSOR, 2010). The country has also enacted different laws that promote and safeguard SDH. Thus, under the title La accesibilidad a los medios audiovisuales: la narración en lengua de señas argentina y el subtitulado para personas sordas [Accessibility to audiovisual media: narration in Argentinean sign language and subtitling for deaf people], official guidelines concerning SDH and accessible media products have been enacted by Argentina's Instituto Nacional de Cine y Artes Audiovisuales [National Institute for Cinema and Audiovisual Arts]. According to the writers of these SDH guidelines, "[a]ccess to information is urgent for the D/deaf." Therefore, these SDH guidelines follow two principles: (1) "building social inclusion" and (2) "hearing and considering the D/deaf users' perspectives" (Massone \& D'Angelo, 2011, p. 11). ${ }^{4}$

\footnotetext{
${ }^{4}$ The English renditions of the texts cited in this article were provided by the authors for lack of an official translation.
} 
Colombia has likewise created laws in support of inclusive television, and the Instituto Nacional para Sordos [National Institute for the D/deaf] published a booklet in 2010 about accessibility of AV products. In this booklet, they demand SDH and narration in Colombian Sign Language for special bulletins, news broadcasting, and government-endorsed programs. Notwithstanding, the extensive documentation does not provide official Colombian guidelines to state the rules of good SDH practices in the country.

The Consejo Nacional para las Personas con Discapacidad (CONAPDIS) [National Council for People with Disabilities] from Venezuela published the 80-page long Manual Instructivo de Accesibilidad para las Personas con Discapacidad (2000) [Accessibility Instructional Manual for People with Disabilities], in which design-for-all plans for housing, urbanism, and public transportation are established and explained, with illustrations. This accessibility manual also includes guidelines for journalists to interview the $\mathrm{D} /$ deaf and provides information on laws that ban humiliation of people with disabilities on public television, but there are no local SDH guidelines.

All other Spanish-language SDH norms consulted offer different solutions to the same problems and they all include solutions to problems not addressed in other guidelines. The following guides and documents from Spain were analysed: the manual by Una Norma Española (UNE) Subtitulado para personas sordas y personas con discapacidad auditiva (2012) [A Spanish Standard (UNE) Subtitling for the Deaf and Hearing Impaired]), and García-Crespo and Quintana's Guía de metodología básica para el subtitulado de vídeos (n.d.) [Basic methodology guide for video subtitling]. Furthermore, we also consulted Díaz-Cintas' Competencias profesionales del subtitulador y el audiodescriptor (2006) [Professional skills of the subtitler and audio writer], a relevant document in training even if it is not an SDH standard.

Lastly, we also consulted SDH guidelines for subtitles aimed at the Latin American communities in the United States drafted and internally published by the following private companies: Netflix (Translation Guidelines and Subtitling Facts, both documents sent to remote translators in 2012); Participatory Culture Foundation, creators of the Amara Subtitling Platform (Amara On Demand Subtitling Team Internal 013 Handbook, 2013); and ZOO Digital Production LLC (Abbreviated Subtitle Style Guide, 2014). Thorough and detailed comparison of which suggestions are included and which omitted by each of these SDH standards guides is offered in the form of a table (in the form of tables) in the first chapter of González-Irizarry's dissertation draft (González-Irizarry, 2020).

\section{Methodology}

Our research questions are based on the aforementioned information on accessibility regulations and SDH standards, mostly in Latin America or aimed at Spanish-speaking Latin Americans: Which laws have been enacted in Cuba, the Dominican Republic, and Puerto Rico in the interest of the D/deaf population? Are there cinema laws concerning media accessibility? Does the D/deaf community in each island have equal access to media or AV products? How are media and AV products consumed? Are there local SDH regulations or guidelines? Are they complied with? 
For this paper, we follow a descriptive methodology with a comparative perspective by: presenting an overview of the $\mathrm{D} /$ deaf's living conditions in each island and the laws in force pertaining to the $\mathrm{D} /$ deaf, design-for-all approaches, and SDH as a tool to access media; showing the type of AV products D/deaf consumers watch in each country; and outlining the difficulties of each D/deaf community with access to media and entertainment. Following the descriptive methodology, the objective of this paper is to shine light on D/deaf media accessibility according to legal and social aspects of the Spanish-speaking Greater Antilles while delimiting the needs of the Cuban, Dominican, and Puerto Rican D/deaf with regard to media accessibility, particularly SDH. The social, economic, and political conditions of each island under study have severely restricted data collection concerning (media) accessibility. The facts stated above, combined with poor and complex archival and data storing systems (to cite an example: missing or stolen documentation and other useful data that should be carefully recorded), limited access information, and difficult conditions and prevents us from adopting other methodological approaches.

\section{Cuba}

Access to information on living conditions and jurisprudence in Cuba has been the most limited. The political situation and the economic embargo placed on Cuba by the United States (and later other countries), hinders access to information in Cuba. To retrieve as much relevant information as possible, we have referred to Cuban governmental and private web sites as well as documentation brought forth by a Puerto Rican librarian, Ana Espinoza-Cancel (A. Espinoza-Cancel, personal communication, February 13, 2017-March 17, 2017).

\subsection{The Cuban D/deaf Community}

According to the 2012 Cuban Census, among the total population of 11.5 million people, there were $60,570 \mathrm{D} /$ deaf individuals. This number is divided as follows: in urban areas, there were 27,756 Deaf and 48,643 hard of hearing persons. Meanwhile in the rural areas, there were 7,454 Deaf and 11,927 hard of hearing persons. Our research on the Cuban D/deaf community shows that legislators consider this population when enacting both constitutional laws and regulations concerning accessibility for people with disabilities. For example, the Cuban government makes education a priority for its people: the Cuban education model sets guidelines and high standards for the education of $\mathrm{D} /$ deaf people.

\subsection{The Cuban Education Model}

The Cuban D/deaf community is under the Cuban Education Model. There are an estimated 20 schools for D/deaf people throughout the island, divided as follows: at least one school for the D/deaf in each of the 15 provinces of the country, and three more in the capital, Havana (Tomayo, 2001). A 
series of law subsections in the 2004 Cuban Education Model state that all D/deaf children and teenagers must learn two languages at the same time: Cuban Sign Language as a first language and spoken/written Spanish as a second language. By enforcing this law, D/deaf people receive education in their communication system as well as in the communication system of the hearing population. As a result, they are able to communicate with all people, both $D /$ deaf and hearing, enhance their sense of Cuban culture, and develop their identity as a D/deaf individual within the D/deaf community (Pérez-Gallardo, 2015). In addition to the bilingual system in place, the government's efforts to include the $\mathrm{D} /$ deaf in the hearing community reach all school grounds. In schools for the general population, Cuban Sign Language has been used and taught since 1994 (Tomayo, 2001). The Cuban Education Model seeks to provide D/deaf students with a system of specialized schools that will prepare them for higher education or, if they transition to schools with hearing students, the state funds sign language interpreters therein. Furthermore, regulations that ensure civil rights for people with disabilities are enacted to guarantee that the D/deaf are well-prepared to become part of society, and that no communication barriers affect their career opportunities, legal awareness, access to recreational activities, and engagement with others (Pérez-Gallardo, 2015).

\subsection{Viewing Habits of AV Products in Cuba}

The Cuban government exerts strict control on the different media, including the AV products the Cuban population may watch. According to Radio Televisión Martí (Cuba, cintas de video..., 2016), AV content is limited, for the most part, to local movies, TV programs, and news, and some local AV production is hard to distribute. For example, movies made by students and independent productions that win national awards hardly make it to the screen or movie theatres. This has resulted in an on-going debate between scholars and lawmakers, who seek to broaden the audience of these productions. At the time of writing, no significant action from the government has been taken.

Concerning foreign AV products, Cuba's appetite for American productions has created a void filled by unauthorized use and reproduction thereof and a local black-market of pirated foreign films, which are translated and subtitled illegally by locals for CUP $\$ 530$ to $\$ 1,060$ (USD \$20 to $\$ 40$ ) per video (Cuba, cintas de video..., 2016).

\subsection{AVT Laws and Regulations}

Although it is mentioned in several documents and online media, such as Tomayo's article on the education of D/deaf Cubans (2019), Leonardo Pérez-Gallardo's book on civil rights of Cubans with disabilities (2015), and court resolutions published in Cuba's official gazette, La Gaceta Oficial de Cuba [see, as example, Resolución No. 44/2019 (GOC-2019-521-043)], so far we have been unable 
to obtain a copy of the Ley de Cine de Cuba [Cuban Cinema Act]. ${ }^{5}$ We have likewise been unsuccessful in finding laws or regulations that govern the consumption of and accessibility to AV products. Nevertheless, we consider it important to share our findings concerning Cuban cinema production according to news, articles, and similar online or documentary evidence.

The Instituto Cubano del Arte e Industria Cinematográficos (ICAIC) [Cuban Institute of Cinematographic Art and Industry] was created by Act No. 169 of 1959. This was the first cultureoriented legislation enacted by the government, two months after the Revolution's victory. This act created the Cuban cinema in all its aspects and stages: production, distribution, and screening. Since then, the creation of Cuban cinematographic products has been under the State's complete and absolute control (Cineastas cubanos..., 2015). As stated in Cineastas cubanos aprobaron propuesta de ley de cine, con el ICAIC [Cuban Filmmakers Pass Film Bill with ICAIC] and quoting the text of Act No. 169: "The distribution and screening of cinema products fulfils a cultural role that must be in the hands of the State." [...] Furthermore, the act promotes foreign investments in cinema:

In today's Cuba, we are able to foresee an increase in the creation of local audiovisual products and foreign producers who are interested in filming in Cuba or investing in specific areas of the audiovisual system, such as production and post-production, screening, and marketing (Cineastas cubanos..., 2015).

Likewise, the act stresses the necessity on the part of the State to control cultural productions: "In a world saturated with foreign AV works, many of them produced by the homogeneous and global industry of entertainment, protecting and encouraging local AV productions is a dire need in order to protect and develop the Cuban culture."

Decree Act No. 373 of Independent Audiovisual and Cinema Producers, which overrides Resolution 160 of December 4, 2001, enacted by the Cuban Ministry of Culture, was approved by the State Council on March 25, 2019. National and international publications thereof state that said ordinance brought in more freedom for moviemakers, the sanctioning of the Cuban Institute of Cinematographic Art and Industry as the governing institution of Cuban cinema, and the recognition of employment conditions of the independent movie and AV products creator or producer, which in turn is formalized with the creation of the [Cinema] Producer Registry: a legal recognition of working status for the people who work within the AV field (Sautié, 2019). Likewise, this Decree highlights Cuba's economic and marketing opportunities as a strategic venue to film foreign movies: the Decree also creates and officialises the Cuban Film Commission, a body that facilitates local and foreign cinema production, promoting Cuba as a destination for AV productions, as part of a strategy to generate income and increase employment in the cinema industry. Finally, the Decree continues to establish that the Cuban government keeps total control and power over all AV products. Regarding

\footnotetext{
${ }^{5}$ The original act dated from mid-twentieth century is online. However, the full and current complete act is not online, and although it is a public document, it is not publicly available. We have retrieved and used in this paper information obtained from parts of one of the most recent amendments (if not the most current) quoted in "Cuba, la ley Núm. 169" and published in Cinémas d'Amérique Latine 17 (2009).
} 
the above, several subsections of Resolution No. 44, concerning Decree Act No. 373 are presented below:

WHEREAS: The Cuban Institute of Cinematographic Art and Industry, subordinated to the Ministry of Culture, has the following duties:
a) $[\ldots]$

b) to approve the audiovisual content that may be screened in movie theatres, as well as direct, control, and execute their distribution and screening;

c) $[\ldots]$

d) to foster the cinematographic and audiovisual culture within the population, as well as supporting the events that take place during screenings;

e) to guarantee that the cinematographic memory of the country is retrieved, restored, conserved, digitalized, recorded, protected, socialized, promoted, preserved, and open to the public;

f) to direct and control the production, programming, and screening of animated audiovisual works meant to provide an ethical education, particularly of children and teenagers;

g) to direct, control, and execute the policies related to the production and marketing of the country's cultural cinematography's goods and services, as well as the exportation thereof;

h) $[\ldots]$

i) to direct and control the businesses that sell or rent audiovisual products, in order to promote and spread Cuban and international cinema, as well the education of an active viewer;

j) $[\ldots]$

k) $[\ldots]$

I) $[\ldots]$ 
m) to regulate, assist, and supervise the technical aspects of the organization and operation of the country's movie theatres;

n) $[\ldots]$

o) to control the use of cinematographic works in the Cuban Institute of Radio and Television and other entities dedicated to audiovisual content programming and distribution.

The Republic of Cuba is the pioneer in the Caribbean when it comes to enacting laws that regulate its inclusive education system or benefit the D/deaf community. Yet, neither the amendment of the 1959 Cinema Act nor the Decree Act No. 373, which are the fundamental pieces of legislation we have gained access to, have provisions for creating accessible cinema. However, we believe that the subsequent amendments to the Cinema Act include provisions that regulate accessible AV products, but it has been impossible to find the most recent amendment concerning subtitles for the D/deaf or recent text of said law. Similarly, we have not found scholarly or published works that provide evidence of the existence of a manual regulating both standard subtitles and subtitles for the D/deaf in Cuba.

\section{The Dominican Republic}

Even if there is no embargo on the Dominican Republic, much of the data we hoped to find was inaccessible or is limited in content. Both Liberato Tavárez, a Dominican writer, and Odalis Martínez, a Deaf Dominican woman, confirm that there are no laws demanding the use of close captions or SDH in all or most AV material, and if there are, they are being blatantly ignored. (O. Martínez \& L. Tavárez, personal communication, April 13, 2020). Nonetheless, "not all D/deaf know Dominican Sign Language" (O. Martínez, personal communication, April 13, 2020), making it impossible for them to access information on urgent topics such as weather forecasts, hurricane warnings, and daily news. Moreover, according to our documentary research and Martínez (2020), there is no website, institution, or person dedicated to the standardization of SDH in the country.

\subsection{The Dominican D/deaf Community}

The Dominican D/deaf community faces a peculiar social situation: While progress concerning the protection of the rights of the $\mathrm{D} /$ deaf has been made, policymakers on the island still have a long road ahead. In order to provide understanding about Dominican society and law concerning the $D /$ deaf, three interesting facts need to be pointed out:

- In 2000, D/deaf people were granted the right to drive a motor vehicle. 
- Eight years later, a Sign Language Act was enacted, providing more education access to the $\mathrm{D} /$ deaf community by guaranteeing sign language interpreters to university students. These interpreters earn a salary of DOP [Dominican Pesos] 20,000 to 45,000 [USD \$390 to \$880] every month, paid by the government (López, 2019).

- The rights of people with disabilities were specifically protected by the Dominican Constitution in 2010.

Despite the progress achieved, there is no census to help us estimate the D/deaf population in the Dominican Republic, just like there is no census of how many people are blind or visually impaired, or how many people have some other physical, sensory, or mental disability. The latest Dominican census was published in 2018, and although it states how many disabled Dominicans live on the island, it does not provide any other information. There is no clear number on how many D/deaf live in the Dominican Republic, but according to people who lead projects for the D/deaf community, such as the director of the Asociación Nacional de Sordos de la República Dominicana (ANSORDO) [Dominican Association for the Deaf], there are between 95,000 and 145,000 D/deaf individuals in the Dominican Republic, about $1 \%$ of the total population, 50,000 of which are children and teenagers of school age (Hiraldo, 2012). On the brighter side, there are about 20 schools exclusively for $\mathrm{D} /$ deaf students in the Dominican Republic and there is a government body devoted to finding employment for D/deaf persons who have at least attained a high school diploma and are able to communicate both in Spanish and in Dominican Sign Language. However, the latter has been criticised in the Dominican media as not being fully efficient, since the D/deaf who hold at least a bachelor's degree work in blue-collar jobs and most find employment only as janitors (López, 2019).

\subsection{Viewing Habits of AV Products in the Dominican Republic}

As the information we have access to is limited, we have not been able to find evidence-based data in regard to traditional $\mathrm{AV}$ consumption, such as movies broadcast on TV, local television programmes, and both local and foreign movies screened in movie theatres. On the positive side, Tavárez and Martínez have assisted us in this matter. According to their statements, most of the films enjoyed by Dominicans are locally produced or come from the United States and, to a much lesser degree, other foreign countries. Consequently, "the screening of American cinema has increased in both movie theatres and local television" (L. Tavárez, personal communication, April 13, 2020). European and Latin American films are not common, yet Dominicans enjoy these in international movie festivals held in the island.

Dominicans love their local cinema and the Spanish language. We love watching movies made here and the consumption thereof is high. When American movies are screened, we like them dubbed into Spanish, especially animated movies, which are almost never imported in their original English versions. The preference for subtitled movies has decreased significantly (L. Tavárez, personal communication, April 13, 2020). 
Even if local film production is welcomed by Dominicans, Tavárez and Martínez (personal communication, April 13, 2020) argue that, to their knowledge, there is no Dominican film with SDH. We have not been able to find one Dominican movie with closed captions or SDH either. However, Dominicans use current technologies to enjoy AV products. According to the Oficina Nacional de Estadística (ONE) [National Statistics Office] (2019), 60\% of the Dominican Republic's population has Internet access. Their report also states that $61 \%$ of those users are women and $65 \%$ of them belong to the Millennial generation. Based on the country's economy, these figures presuppose a high Internet consumption and number of users. ONE's report furthermore states, in order of importance, the three types of digital content Dominican users prefer: AV content found on YouTube, Netflix, and online TV streaming channels. Of course, these companies include closed captions, SDH, or automatically generated subtitles on their video content. Therefore, the Dominican D/deaf community with Internet access has high chances of enjoying accessible AV products.

\subsection{AVT Laws and Regulations}

The General Law on Disability in the Dominican Republic (Act 42-2000) outlines the obligations of the entities involved in the development and social integration of people with disabilities. These obligations are divided into three categories: social, family, and state obligations. Therein is also defined the Dominican National Council on Disability (Consejo Nacional de Discapacidad, CONADIS), which is the governing organization of the sector and has several areas of operation, two of which are the socioeconomic and educational integration. Both this body and the General Law on Disability in the Dominican Republic are important steps on the way to offering the D/deaf access to AV products.

Although no information is provided concerning Dominican films, the act provides the hearing impaired with access to all telecommunication programs of high public interest, such as news and special broadcasts concerning weather or criminal alerts. Specifically, Act 42-2000, section 85, paragraphs I and II, provides that all telecommunication programs should include an interpreter of sign language, SDH, or closed captioning, and screen readings of the texts that appear on screen (for the blind). The above is partially confirmed by Tavárez:

Local television does not have a channel or program that incorporates subtitles for the $\mathrm{D} /$ deaf. Some newscasts care enough to provide a sign language interpreter, and the person interpreting the news can be seen in the corner of the screen

(L. Tavárez, personal communication, April 13, 2020).

As a penalty for operating against the law, the CONADIS has authority to order a temporary suspension of the operations until the production houses can fulfil the needs for blind and D/deaf viewers. However, the authorities have not enforced this law uniformly: these programs are not always closed captioned or subtitled for the D/deaf and they continue to be screened (Santana, 2015). The above has become an urgent topic of discussion both among the D/deaf and people who 
work for them, as well as an issue raised by social activists both in the academic sector and in the media (Santana, 2015).

Until today, we have found no locally-produced Dominican movies that would incorporate closed captions or SDH, nor any local guidelines for SDH.

\section{Puerto Rico}

The island of Puerto Rico has a peculiar government system as it has been an unincorporated territory of the United States since July 25, 1952. Furthermore, Puerto Ricans have had U.S. citizenship since 1917, and the island had been under U.S. military government since its invasion in July 25, 1898 until it became an incorporated territory of the U.S. (Picó, 2008). Therefore, in terms of law and languages, Puerto Rico is different from Cuba and the Dominican Republic. For example, federal laws of the United States have hierarchy over commonwealth laws. Besides the laws concerning local TV production, all other laws pertaining to AV content aimed at people with disabilities only exist at the federal level, as they have not been enacted under the commonwealth law system. Concerning the language written and spoken in the island, Puerto Rico has two official languages: English and Spanish, the latter being the most widely used in everyday life (Welcome to Puerto Rico, 2020). Most Puerto Ricans have a beginner's level of the English language, although spoken Spanish is under strong English influence, which leads to the use of neologisms and Spanglish, a combination of words and syntax of both English and Spanish.

\subsection{The Puerto Rican D/deaf Community}

According to the 2010 Census, there are about 139,000 D/deaf individuals in Puerto Rico. This number corresponds to $3.8 \%$ of the total population living on the island, which is estimated at about 4 million people) (Departamento de Comercio de los EE. UU., 2012). Figure 1 below shows percentage distribution by age group: 
Figure 1.

Percentage of $D /$ deaf Puerto Ricans

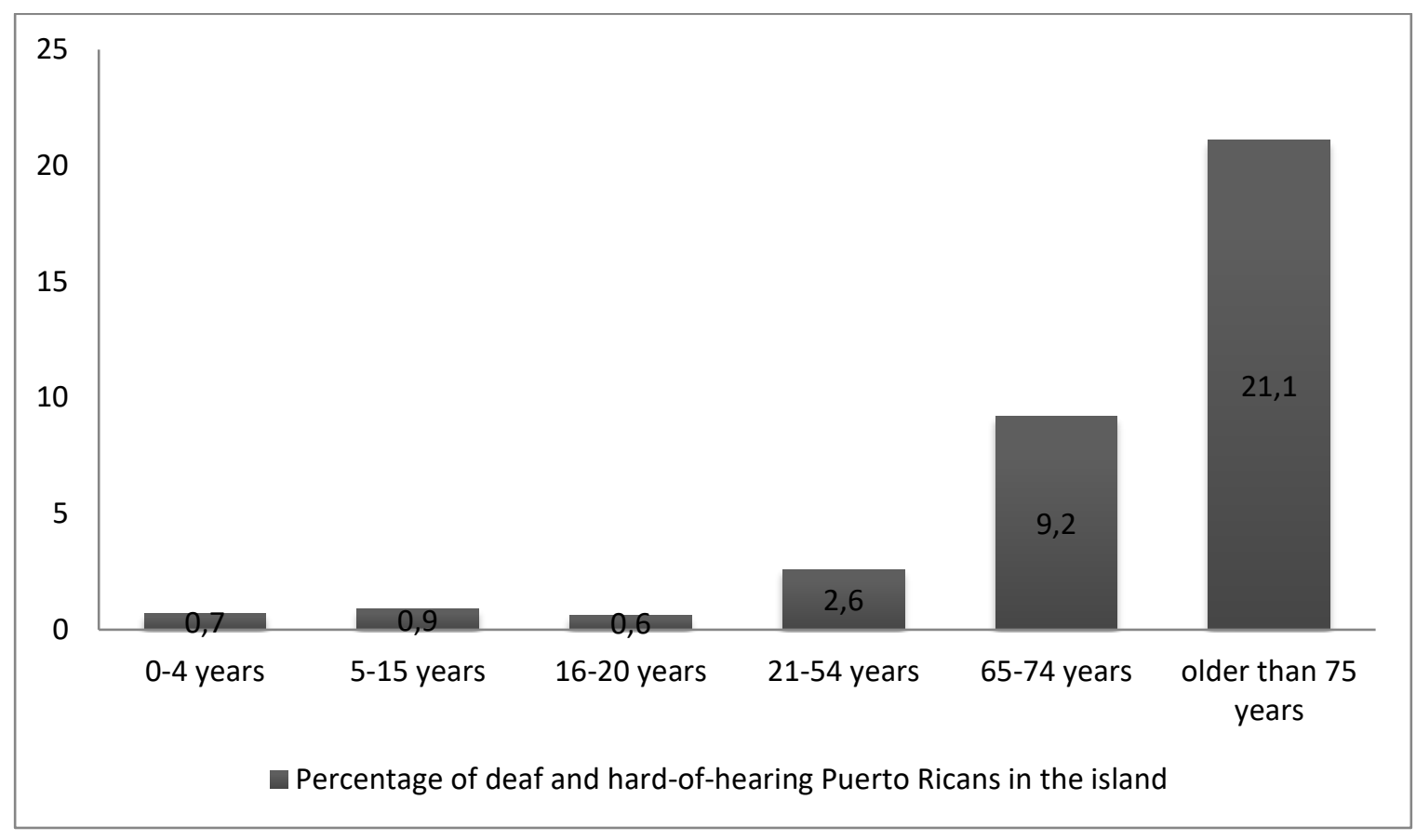

Source: Departamento de Comercio de los EE. UU., 2012

According to the standards defined by the US Statistical Policies Directive 14 (Erickson, Lee \& von Schrader, 2010), most of these people live in poverty. Furthermore, education for the D/deaf is limited. Currently, a handful of semi-private schools offer elementary, middle, and high school education in sign language only (Alternativas..., 2011). Yet,

regardless of the number of $D /$ deaf in Puerto Rico, no matter if they are children or adults, there are no education opportunities that provide the $D /$ deaf with an adequate exchange of knowledge that fulfil their intellectual needs, because the island has no specialized schools that allows them to pursue higher education (Ramos-Ramos, 2010, p. 94).

Students who are D/deaf and cannot attend any of these semi-private schools for the D/deaf due to economic and/or geographical barriers (e.g., two are located in the island's capital, San Juan, while a very few may be found in other municipalities, such as the Christian School and Chapel for the Deaf in Luquillo, in the northeast) ${ }^{6}$ may be sent to groups of special needs children in regular public schools or even public schools for children with special needs, but this does not mean that they are equipped with resources tailored to the D/deaf. Regardless of the school chosen, they are usually placed in mixed groups with children who mostly have psychological and intellectual developmental disorders.

${ }^{6}$ There are private schools throughout the island specialized in the education of the D/deaf, such as the Colegio de Niños Sordos Fray Pedro in Ponce, located on the south. Yet, most of these do not include all school levels and, for economic reasons, they are not even an option for many D/deaf. 
Therefore, D/deaf students are not provided with the tools they need to succeed, such as teachers who can communicate in sign language or sign language interpreters. As a result, as shown in Figure 2 below, according to the 2010 Census, $40 \%$ of the Puerto Rican D/deaf population has not completed basic high school education, and even for those who have completed it, the education levels are considerably lower than the standard set by the hearing population. Not only is there the usual education gap amongst $\mathrm{D} /$ deaf persons, but there is also a bigger education gap between the hearing population and the D/deaf population (Ramos-Ramos, 2010). Hence, before engaging in any Spanish SDH project, translators should consider the specific situation of the Puerto Rican education system for the D/deaf and how this has an impact on the understanding of written Spanish, since AV translations should be made while taking into consideration the median level of comprehension and understanding of the written language by the D/deaf.

Figure 2.

Education Level of Puerto Rican D/deaf Population

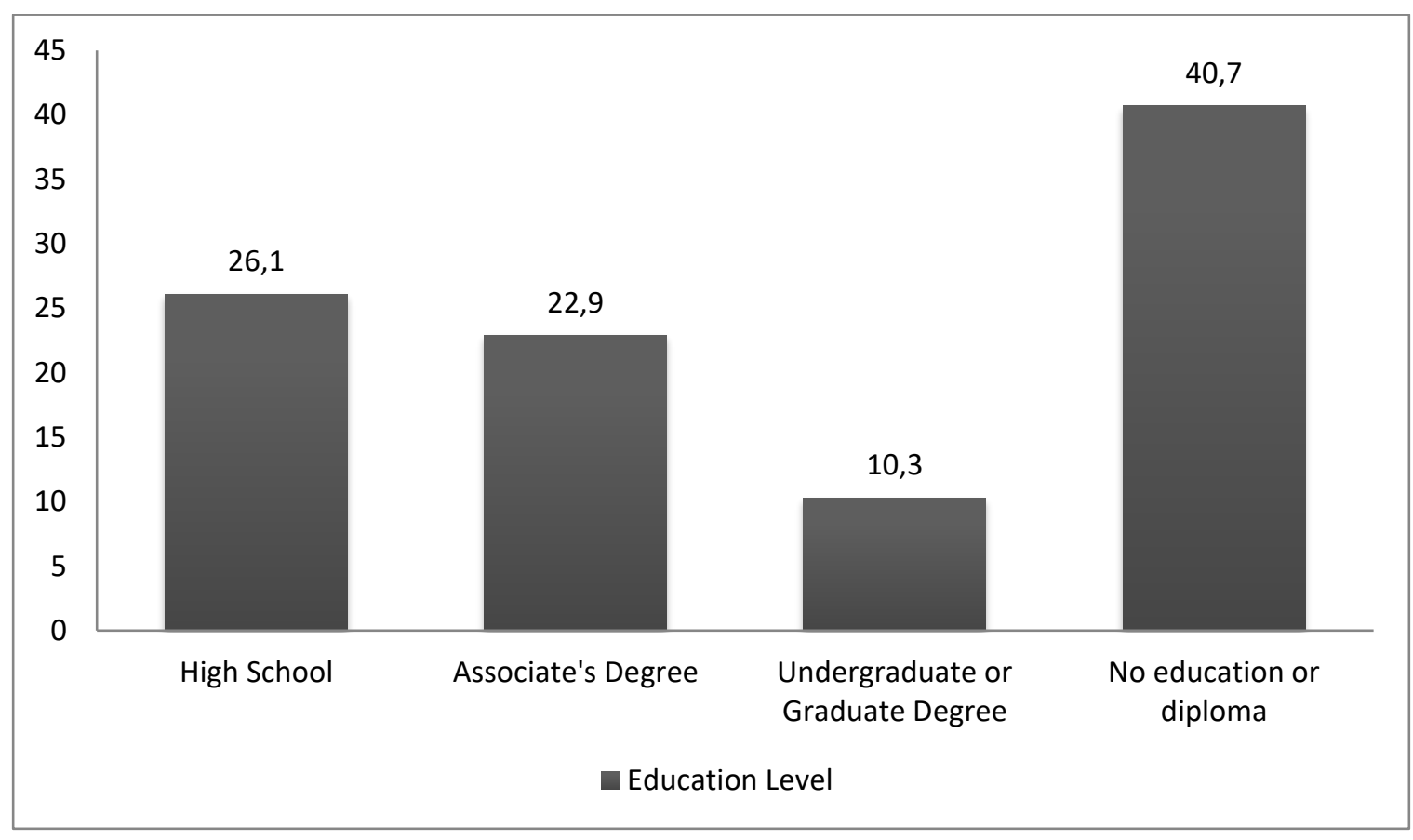

Source: Departamento de Comercio de los EE. UU., 2012.

Another aspect that we deem important to consider when talking about AVT tailored to the D/deaf community in Puerto Rico is their communication system. At present, D/deaf Puerto Ricans use four communication systems (see Williams \& Parks, 2012):

- American Sign Language, which is taught in schools for the D/deaf;

- Puerto Rican Sign Language, a variation from American Sign Language and uses both Spanglish neologisms and Puerto Rican slang;

- Signing Exact English, a communication system, not a language, that uses English grammar and vocabulary to create signs and fingerspelling in order to provide and receive information; 
- and Signing Exact Spanish, in this case, the Puerto Rican Spanish variation of Signing Exact English.

To communicate with the hearing community, some D/deaf use dactylology or fingerspelling (Williams \& Parks, 2012) with people that may know it, such as family members, friends, or other people working directly within the $\mathrm{D} /$ deaf community. D/deaf people who have attained at least a high school diploma have an average understanding of written Spanish (A. Reyes, personal communication, September 15, 2017).

\subsection{Viewing Habits of AV Products in Puerto Rico}

Another aspect to consider when talking about possible regulations in subtitling for the $\mathrm{D} /$ deaf is the viewing habits of AV products in Puerto Rico. Because of the political and economic proximity to the United States, most AV products consumed by the population of Puerto Rico are commercial US movies and TV series. Due to social, geographical, and educational barriers, only a small percentage of the general population is exposed to foreign and local movies. ${ }^{7}$ Movies imported from the United States are screened in movie theatres in English with Spanish subtitles. The subtitling of these movies is never performed in Puerto Rico. Distributing companies pay in-house translators or translation agencies, mostly based in New York or California. According to co-author González-Irizarry's experience (2015: LXII), these, in turn, hire Spanish speaking citizens of the USA (usually Latin American immigrants, not necessarily Puerto Rican, who were raised in the USA by Spanish-speaking parents) and remote workers from South and Central America, Movies for children, on the other hand, mostly come in dubbed into neutral Latin American or standard Spanish. Usually, the task is performed in Argentina or Mexico, particularly in the case of Disney movies (TAV Argentina, 2017). Although Puerto Rico was once a major dubbing country (Fuentes-Luque, 2014), there are currently no studios or translation agencies dedicated to dubbing and subtitling.

Co-author González-Irizarry (2015: LXVIII) states that the Puerto Rican D/deaf receive the exact same AV products as the general population. In other words, these are not tailored to their specific needs: they do not include closed captions or SDH. However, the main cinema chain of the island, Caribbean Cinemas, claims that their Cine para Todos (Movies for Everyone) program is inclusive and that it provides equal accessibility to media for all viewers. The name of the program might suggest that Caribbean Cinemas caters for the needs of persons with sensory difficulties, such as audio description

\footnotetext{
7 This statement is provided as a life-long observation of one of the co-authors, González-Irizarry, who lives in Puerto Rico, where she was also born and raised. All local production (except for some comedies, which get island-wide screenings) and foreign films are screened in either of the two Fine Arts cinema theatres located in the municipality of San Juan, the island's capital. Only upscale individuals and culturally oriented people either can afford or are deeply interested in this type of cinema. However, that is not the case for most of the population, who live in other regions and/or do not have the means to pay for expensive movie tickets.
} 
for the blind and subtitles for the D/deaf. However, Movies for Everyone is far from being inclusive: Caribbean Cinemas only offers specific screening times with lowered soundtrack and less lighting to help persons with autism enjoy the movie experience (Negocios Metro, 2014). Concerning American movies broadcast on local television, such screenings feature dubbing, usually carried out in Mexico. As for straight-to-DVD movies, Puerto Ricans do not receive the same movies as other Spanishspeaking countries in South America, Central America, or the Caribbean. The people on the island can purchase the movies as marketed in the USA. They all come with English closed captions, as ruled by the federal government, and some of them with interlingual subtitles (English > Spanish) (FuentesLuque \& González Irizarry, 2019). As a result, the Puerto Rican D/deaf community is left behind, and their access to AV products is limited.

\subsection{AVT Laws and Regulations}

The United States has been one of the pioneering countries as regards AVT and accessible AV products. Díaz-Cintas and Remael (2014, p. 20) explain that

[t] he USA has a long history of subtitling for the deaf and the hard of hearing, which is reflected in some pioneering legislation in this field and in high percentages of AV programs with intralingual captions -i.e. from English to English-for these social groups.

As early as 1940, Cuban deaf actor Emerson Romero tried to adapt movies for the D/deaf population (Oviedo, 2007). Yet, it took more than a decade for the first SDH to appear in American movies and many more for captions in public TV. According to Izard (2001, p. 169), the first open captions ${ }^{8}$ for the D/deaf appeared in the United States in 1973 in public late-night news broadcasts. Creating SDH (and captions, later) led the U.S. to enact and amend laws concerning AV products and the D/deaf communities. One of the most notorious acts on this matter is Public Law 85-905, enacted on September 2, 1958. The said act provides the following in its statement of motives:

AN ACT to provide in the Department of Health, Education, and Welfare for a loan service of captioned films for the deaf.

Be it enacted by the Senate and House of Representatives of the United States of America in Congress assembled, that the objectives of this Act are-

(1) to bring to deaf persons understanding and appreciation of those films which play such an important part in the general and cultural advancement of hearing persons;

\footnotetext{
${ }^{8}$ Open captions are titles that all viewers see, hearing and D/deaf, and they cannot be removed from the screen.
} 
(2) to provide, through these films, enriched educational and cultural experiences through which deaf persons can be brought into better touch with the realities of their environment; and

(3) to provide a wholesome and rewarding experience which deaf persons may share together.

Today, the Federal Communications Commission is the entity in charge of enforcing the federal laws which state, in sum, that no movie can be screened or marketed within the USA without English closed captions. Beginning in 2003, and as stipulated by the Federal Communications Commission, all movies screened in TV channels must have closed captions for the D/deaf (Pereira-Rodríguez, 2005, p. 163).

Since national regulations concerning AV products are federal laws which have not been enacted in Puerto Rico, and because of the loopholes in those federal laws (which only consider the English language) and the poor oversight of such laws in the island, the federal laws concerning closed captioning and SDH fail to be properly enforced. As a result, movies are screened and sold without Spanish closed captions or Spanish SDH.

In the national legal corpus, however, Puerto Rican lawmakers included a subsection in Act No. 80 of June 9, 2002 (8 L.P.R.A. § 814), titled Sign Language and Closed Captions, which provides that:

- All news broadcast from Monday to Friday from 5:00 p.m. to 7:00 p.m. must include sign language or closed captions. Watching local television programming allows to confirm that this is currently being fulfilled.

- Visual captioning or open captions should be used when broadcasting special bulletins by the Emergency Alert System. Watching local television programming allows to confirm that this is currently being fulfilled.

According to information given to the sign language interpreter Abdiel Reyes by José Beltrán, president of Servicios Orientados al Sordo Inc. [D/deaf Services Inc.], the movies screened to the D/deaf by D/deaf Services Inc. are subtitled by Dicapta in the United States (A. Reyes, personal communication, September 15,2017$).^{9}$

\footnotetext{
${ }^{9}$ In 2014, González-Irizarry began standardizing Spanish SDH in Puerto Rico. Since there are no local guidelines, she created a reference guideline for her M.A. thesis, in which she translated and subtitled a documentary about D/deaf artists and partially localized the film's web site (González-Irizarry, 2015). Today, she is working on her dissertation La subtitulación para personas sordas y personas con deficiencias auditivas: Propuestas normativas y análisis de necesidades en Puerto Rico [Subtitling for the Deaf and Hard of Hearing: Policy Proposals and Needs Analysis in Puerto Rico] (2020), whose aim is to write and publish the first Spanish SDH guidelines specifically tailored to the D/deaf in Puerto Rico. In order to complete this research project, she has written a draft of the questionnaire to be completed by a group of Puerto Rican D/deaf concerning their SDH preferences and needs. González-Irizarry's work aims to propose different projection methods than the ones preferred and discussed in SDH guidelines of Spain, Latin America, and the
} 


\section{Conclusion}

Understanding the need for subtitling for the D/deaf in different Spanish-speaking contexts is urgent. In this paper we have presented an overview of the D/deaf population, regulations on accessibility, and living conditions of the D/deaf in the Greater Antilles of Cuba, the Dominican Republic, and Puerto Rico. This research brings focus to the Caribbean, a hardly known part of the world in the AV context. The information presented will aid translators and lawmakers in these islands in overcoming the current social, legal, and technological/AV barriers in order to establish appropriate AVT norms tailored for their D/deaf. Translators and legislators should work together to meet the specific needs of each D/deaf community and draft Spanish SDH guidelines to be used in these islands. These regulations and guidelines may address the following: preferred typographical conventions; reading speed; maximum amount of characters per line (CPL) and characters per second (CPS); new, modified, or updated SDH standards; etc. Providing accessible subtitles in movies will boost the marketing and sales for local cinemas, since many D/deaf state that they "watch foreign movies, because they are subtitled [for the D/deaf]" (Massone \& D'Angelo, 2011, p. 9). Further research on the matter, such as González-Irizarry's dissertation (2020), is therefore necessary, yet we hope that this article may be of value to translation scholars and translators. It is of paramount importance to start implementing appropriate AVT regulations in the Caribbean region that can be shared with or replicated in other yet similar socio-geographical and linguistic contexts. It has become imperative to

United States, and includes solutions to problems not discussed in those other Spanish SDH guidelines, such as the subtitling of sign language for the hearing population, since she has come across movies in which there are characters or subjects that use sign language or fingerspelling to communicate while both on and off screen. This situation led her to come up with possible rules or new SDH standards (see below) that may be used when subtitling information given in any of the communication systems used by the D/deaf, but foreign to hearing persons. Furthermore, her finished work will consider the social, political, and economic realities of the island. Specifically, González-Irizarry addresses the following SDH parameters:

- the preferred typographical conventions:

- italics, small caps, ellipsis;

- em dash, en dash, or colours to identify dialogues;

- ways to identify off-screen voices and sounds;

- ways to state interrupted dialogues and changes of characters as they speak; etc.

- the reading speed of the Puerto Rican D/deaf community, for which she takes into consideration aspects such as the time when the hearing was lost, the degree of hearing loss, the knowledge about the language in which the subtitles will appear (in this case, Spanish), and the average level of education;

- the maximum amount of lines and characters per line (CPL) and second (CPS); and

- new SDH standards, such as subtitling sign language and other communication systems used by the D/deaf for hearing people. This item also includes some of her preferred takes on previously discussed SDH standards or the integration of two precedent solutions into a new one. These alternatives are part of the questions concerning the identification of speakers, how to signal context information, how to subtitle music, etc. 
bridge the gap between $\mathrm{AV}$ products and the D/deaf, particularly in lesser known contexts and regions, where there is great need for media for all.

\section{References}

Act No. 80 (2002, June 9). Puerto Rico. Para disponer que se utilice el lenguaje de señas en todos los noticiarios locales televisados y el sistema de "Closed Caption" en los boletines del Sistema de Alerta de Emergencia [The official English title of this law in Puerto Rico is: Sign Language and Closed Captions].

Alonso, F. (2007). Algo más que suprimir barreras: conceptos y argumentos para una accesibilidad universal [More than just removing barriers: concepts and arguments for universal accessibility]. TRANS. Revista de Traductología, 11, 15-30. doi:10.24310/trans.2007.v0i11.3095

Alternativas para el niño sordo [Alternatives for the Deaf Child]. (2011, February 25). El Nuevo Día. Retrieved from https://www.elnuevodia.com/estilosdevida/hogar/nota/alternativasparaelninosordo-898811

Cineastas cubanos aprobaron propuesta de ley de cine, con el ICAIC [Cuban Filmmakers Pass Film Bill with ICAIC]. (2015, November 2). Radio Televisión Martí. Retrieved from https://www.radiotelevisionmarti.com/a/cuba-ley-cine-icaic-nestor-jimenez/108190.html

Consejo Nacional para las Personas con Discapacidad (2000). Manual Instructivo de Accesibilidad para las Personas con Discapacidad [Accessibility Instructional Manual for People with Disabilities]. Retrieved from https://www.scribd.com/doc/4778815/Manual-instructivo-paraaccesibilidad-de-las-personas-con-discapacidad

Cruz, B. A. D., Guilbe, C. J., \& López, A. R. (2002). Vive la geografía de nuestro Puerto Rico. San Juan, P.R: Editorial Cordillera.

Cuba, cintas de video, subtítulos y piratería. (2016, June 15). Radio Televisión Martí. Retrieved from https://www.radiotelevisionmarti.com/a/cuba-subtitulaje-peliculas-pirateria/124179.html

Cuba, la Ley $n^{\circ} 169$. (2009, November 6). Cinémas d'Amérique Latine Online, 17. Retrieved from http://journals.openedition.org/cinelatino/1735https://doi.org/10.4000/cinelatino.1735

Dammeyer, J., \& Marschark M. (2016). Level of educational attainment among deaf adults who attended bilingual-bicultural programs. Journal of Deaf Studies and Deaf Education, 21(4), 394-402.

Decree Act No. 373 (2019, March 25). Of Independent Audiovisual and Cinema Producers, Cuba, State Council.

Departamento de Comercio de los EE. UU. (2012). Puerto Rico: 2010 Recuento de Población y Unidades de. Vivienda. Retrieved from https://www.census.gov/prod/cen2010/cph-253sp.pdf

Described and Captioned Media Program (2011). 2011 Captioning key (Manual de Closed Caption). Dicapta, Trans. Retrieved from https://dcmp.org/learn/static-assets/nadh52.pdf

Díaz-Cintas, J. (2003). Teoría y práctica de la subtitulación inglés-español [Theory and practice of English-Spanish subtitling]. Barcelona: Ariel.

Díaz-Cintas, J. (2006). Competencias profesionales del subtitulador y el audiodescriptor [Professional skills of the subtitler and audiodescriptionist]. Madrid: Centro Español de Subtitulado y Audiodescripción. Retrieved from https://www.cesya.es/sites/default/files/documentos/informe formacion.pdf 
Díaz-Cintas, J. (2007). Por una preparación de calidad en accesibilidad audiovisual [Towards quality training in audiovisual accessibility]. TRANS. Revista de Traductología, 11, 45-59. doi:10.24310/trans.2007.v0i11.3097

Díaz-Cintas, J., \& Remael, A. (2014). Audiovisual translation: Subtitling. London: Routledge.

Díaz-Navarro, A. (2016). Hábitos de consumo audiovisual: Un estudio enfocado a alumnos de Traducción e Interpretación acerca del doblaje y la subtitulación [Audiovisual Consumer Habits: A Study of Dubbing and Subtitling for Translation and Interpretation Students](Dissertation, Universidad de Alicante, Spain). Retrieved from https://www.academia.edu/27233915/Hábitos de consumo audiovisual Un estudio enfocado a alumnos de Traducción e Interpretación acerca del doblaje y la subtitulación.pdf

Erickson, W., Lee, C., \& von Schrader, S. (2010). Reporte del Estado de la Discapacidad: Puerto Rico [Report on the Status of Disability: Puerto Rico]. Instituto de Empleo y Discapacidad de Cornell University. Retrieved from http://www.disabilitystatistics.org/StatusReports/2010-PDFSpanish/2010-StatusReport PR.pdf

Fuentes-Luque, A. (2014, May 1). Cuando Puerto Rico le hablaba al mundo [When Puerto Rico talked to the world]. University of Puerto Rico, Río Piedras Campus.

Fuentes-Luque, A., \& González-Irizarry, P. L. (2019, June). Subtitling for the deaf and hard of hearing in the Spanish-speaking Greater Antilles. Paper presented at Media for All, 8 International Conference, University of Stockholm, Sweden. Retrieved from https://www.tolk.su.se/english/media-for-all-8/programme/abstracts/subtitling-for-the-deafand-hard-of-hearing-in-the-spanish-speaking-greater-antilles-1.426482

García-Crespo, A., \& Quintana, I. (n.d.). Guía metodológica básica para el subtitulado de vídeos [Basic methodological guide for video subtitling]. Centro Español de Subtitulado y Audiodescripción. Retrieved from https://www.mecd.gob.es/dms-static/1167ae20-0ce44420-a2f6-649ccb7f38d0/2011-guiametodologiasubtitulado-pdf.pdf

González-Irizarry, P. L. (2015). "Manual de subtitulado para sordos y personas con deficiencias auditivas". Traducción y subtitulado para personas sordas y con deficiencias auditivas del documental Mira lo que digo y localización parcial del sitio web de la película: Tesis práctica con énfasis en el uso y manejo de herramientas de código abierto ["Subtitling Manual for the Deaf and Hearing Impaired". Translation and subtitling for deaf and hearing-impaired people of the documentary See what I say and partial localization of the film's website: Practical thesis with emphasis on the use and handling of open-source tools]. [Unpublished Master's thesis], (pp. 263-278). University of Puerto Rico.

González-Irizarry, P. L. (2020). La subtitulación para personas sordas y personas con deficiencias auditivas: Propuestas normativas y análisis de necesidades en Puerto Rico [Subtitling for the Deaf and Hard of Hearing: Policy Proposals and Needs Analysis in Puerto Rico] (Manuscript in preparation. Phd Programme in History and Humanities: Europe, America, Arts, and Language, Pablo de Olavide University, Spain).

Hiraldo, J. M. (2012, July 31). Estiman $1 \%$ de la población en RD es sorda [ It is estimated that 1\% of the population in the DR is deaf]. El Caribe. Retrieved from https://m.elcaribe.com.do/2012/07/31/Idquohablamos-lengua-senas-para-que-todos-nosveanrdquo

Instituto Nacional para Sordos - INSOR. (2010). Por una televisión incluyente: Documentos [For an inclusive television: Documents]. Retrieved from

https://issuu.com/daniel1012/docs/guia para el servicio 
Izard, N. (2001). La subtitulación para sordos del teletexto en Televisión Española [The subtitling of teletext for the deaf on Spanish Television]. In L. Lorenzo \& A. Pereira (Eds.), Traducción subordinada II, El subtitulado: (inglés-español/gallego) [Constrained Translation II, Subtitling: (English-Spanish/Galician)] (pp. 169-194). Vigo: Servizo de Publicacións de la Universidade de Vigo.

Ley General sobre la discapacidad en la República Dominicana (Ley 42-00) [General Law on Disability in the Dominican Republic. No. 42-00). Dominican Republic]. Retrieved from http://www.sipi.siteal.iipe.unesco.org/sites/default/files/sipi normativa/leyno.42-00ley general sobre la discapacidad.pdf

Ley general sobre la discapacidad en la República Dominicana [General Law on Disability in the Dominican Republic]. No. 5-13. Dominican Republic (2013). Retrieved from http://www.senado.gov.do/masterlex/MLX/docs/1C/2/12/20/207/298F.htm

López, M. (2019, September 22). Sordos y oyentes se beneficiarán de ley de lenguaje de señas dominicana [Deaf and hearing people will benefit from Dominican sign language law]. Diario Libre. Retrieved from https://www.diariolibre.com/actualidad/sordos-y-oyentes-sebeneficiaran-de-ley-de-lenguaje-de-senas-dominicana-LP10861684

Massone, M. I., \& D’Angelo, C. G. (2011). La accesibilidad a los medios audiovisuales: la narración en lengua de señas argentina y el subtitulado para personas sordas [Accessibility to audiovisual media: narration in Argentinean sign language and subtitling for deaf people]. Buenos Aires: Instituto Nacional de Cine y Artes Visuales de Argentina.

Negocios Metro. (2014, June 10). Cine para Todos en Caribbean Cinemas. Metro Puerto Rico. Retrieved from https://www.metro.pr/pr/noticias/2014/06/10/cine-para-todos-encaribbean-cinemas.html

Netflix. (2012). Subtitling FAQs. Digital.

Netflix. (2012). Translation Guidelines. Digital.

Neves, J. (August 14, 2008). Training in subtitling for the $d /$ Deaf and the hard-of-hearing.

Oficina Nacional de Estadística (ONE) de Cuba. (2012). Censo de población y vivienda Cuba 2012 [Population and Housing Census Cuba 2012]. Retrieved from http://www.one.cu/informenacional2012.htm

Oficina Nacional de Estadística de la República Dominicana. (2019). Dominicana en cifras 2018 [The Dominican Republic in figures 2018]. Retrieved from https://www.one.gob.do/Multimedia/Download?Objld=90283

Oviedo, A. (2007). Una estrella sorda cubana del cine mudo: Emerson Romero (alias Tommy Albert) (1900-1972) [A deaf Cuban star of silent cinema mudo: Emerson Romero (aka Tommy Albert) (1900 - 1972)]. Cultura Sorda. Retrieved from https://cultura-sorda.org/emerso-romeroactor-sordo-cubano

Participatory Culture Foundation. (2013) Amara On Demand Subtitling Team Internal 013 Handbook.

Pereira-Rodríguez, A. (2005). El subtitulado para sordos: Estado de la cuestión en España [Subtitling for the deaf: State of the art in Spain]. Quaderns. Revista de traducció 12, 161-172.

Pérez-Gallardo, L. (2015). Discapacidad y derecho civil en Cuba [Disability and civil law in Cuba]. Madrid: Dykinson.

Picó, F. (2008). Historia general de Puerto Rico [A general history of Puerto Rico]. San Juan, Puerto Rico: Ediciones Huracán.

Public Law 85-905 (1958, September 2). To provide in the Department of Health, Education, and Welfare for a loan service of captioned films for the deaf. Retrieved from https://www.govinfo.gov/content/pkg/STATUTE-72/pdf/STATUTE-72-Pg1742.pdf - page=1 
Ramos-Ramos, T. M. (2010). El derecho a la educación de las personas con discapacidad auditiva en Puerto Rico [The right to education of hearing impaired people in Puerto Rico]. Revista Clave, 5, 93-120.

Resolución No. 44/2019, Gaceta Oficial de la República de Cuba, GOC-2019-521-O43. República de Cuba (2019). 702-705.

Santana, O. (2015, February 9). República Dominicana, 'en pañales' a la hora de romper barreras a sordos [The Dominican Republic, still 'in diapers' when it comes to breaking down barriers for the deaf]. Diario Libre. Retrieved from http://www.diariolibre.com/noticias/repblicadominicana-en-paales-a-la-hora-de-romper-barreras-a-sordos-CADL1004251

Sautié, M. (2019, June 26). El Decreto ley del creador audiovisual y cinematográfico independiente constituye una fortaleza cultural [The Decree Law of the independent audiovisual and film creator is a cultural strength]. Granma, órgano oficial del Comité Central del Partido Comunista de Cuba. Retrieved from http://www.granma.cu/cultura/2019-06-26/el-decretoley-del-creador-audiovisual-y-cinematografico-independiente-constituye-una-fortalezacultural-26-06-2019-22-06-43

Sokoli, S. (2005). Omisión y distribución de subtítulos en España y Grecia: Cómo y por qué [Omission and distribution of subtitles in Spain and Greece: How and why]. In R. Merino, E. Pajares \& J.M. Santamaría (Eds.) Trasvases Culturales 4: Literatura, Cine y Traducción (pp. 271-283). Vitoria: Universidad del País Vasco.

TAV Argentina (2017, August 28). Disney en el doblaje [Disney in dubbing]. Traductores Audiovisuales de la Argentina. Retrieved from http://tavargentina.com/2017/08/disney-en-eldoblaje

Tomayo, J. (2001, September 6). La educación de los sordos en Cuba [Education for the Deaf in Cuba]. Voces en el silencio. Retrieved from http://www.vocesenelsilencio.org.ar/modules.php?name=News\&file=article\&sid=15

Una Norma Española (UNE) (2012). Subtitulado para personas sordas y personas con discapacidad auditiva [A Spanish Standard (UNE). Subtitling for deaf and hearing impaired people]. Madrid: AENOR.

United States Census Bureau. (n.d.). U.S. and world population clock. Retrieved from https://www.census.gov/popclock

Welcome to Puerto Rico (2020). Puerto Rico's culture: Beyond language. Retrieved from https://welcome.topuertorico.org/culture/language.shtml

Williams, H., \& Parks, E. (2012). The Puerto Rican deaf community. SIL International. Retrieved from https://www.sil.org/system/files/reapdata/34/72/85/34728551201196591377129478439081 104716/silesr2012_005.pdf

Zoo Digital Production LLC. (2014). Abbreviated Subtitle Style Guide. 